DOI: $10.1515 /$ rpp-2015-0020

Doctor of Pedagogical Sciences, Full Professor, LILIA BARANOVSKA

National Aviation University, Ukraine

Address: 1 Kosmonavta Komarova Ave., Kyiv, 03680, Ukraine

E-mail: liliya03.05@ukr.net

Lecturer, ALLA ZASLUZHENA

National Aviation University, Ukraine

Address: 1 Kosmonavta Komarova Ave., Kyiv, 03680, Ukraine

E-mail: alla130373@mail.ru

\title{
CONTENT PECULIARITIES OF BACHELORS' IN ENGLISH LANGUAGE AND LITERATURE TRAINING AT UNIVERSITIES OF SWITZERLAND CONFEDERATION
}

\begin{abstract}
The article is devoted to the content-analysis of peculiarities of Bachelors' in the English language and literature training at Swiss universities. It has been revealed that domestic scientists have not paid special attention to this problem as the issues of future teachers' training and future foreign languages teachers' training in foreign universities, in particular in Germany, USA, Finland, Mexico, Great Britain, Hungary and Japan have been more studied.

The study of curricula at Swiss universities under conditions of credit-modular organization of educational process, which affects the structure of the content, choice of forms and methods of teaching and assessing students' academic achievements has allowed us to conclude that the student learning is based on the multicultural, competent and communicative approaches.

English language learning in the context of general linguistic picture of the world, its style and dialect importance is content particularity of this training. The communicative aspect of English study by Bachelors first appears in content acquirement of subjects "Exploring Sociolinguistics", "Sociophonetics". English is taught in the context of its understanding as a means of interaction under conditions of educational and cultural integration of the nations and a means of constructive polylogue in the country, that represents multicultural vector of bachelors' training in philology.

The experience of Swiss universities can be adopted by native universities to create a multicultural and communicative personality of a future philologist.

Key words: training content, BA in English Language and Literature, university, Bachelor in Philology, integrated specialist, methodological approaches, Switzerland.

\section{INTRODUCTION}

Modern European Community of higher education and science has been founded on the basis of multicultural principle, based on the idea that the content of professional education and future graduates' professional occupation determines human values. In this environment language has to become an integrating means of professional intelligence and high spirituality of future professionals.

English is one of the international languages; its development will contribute to the achievement of understanding at various levels of European and world interaction. In
\end{abstract}


addition, English can add up to promotion of domestic intellectual integration in countries where the language policy is implemented through several national languages. Particularly, this applies to Switzerland. That is what has caused scientific interest to the characteristics of future specialists in English language and literature training, especially, Bachelors in Philology, who study at Swiss universities.

\section{THE AIM OF THE STUDY}

The aim of the study is to identify the characteristic features of the Bachelor' degree in the English language and literature at universities in Switzerland for further application of positive aspects of Swiss experience at universities in Ukraine.

\section{THEORETICAL FRAMEWORK AND RESEARCH METHODS}

Issues of future philologists' training in foreign universities have been studied by: V. Bazova (Germany) (Базова, 2012), B. Bazurina (UK) (Базуріна, 2006), L. Cherniy (USA) (Черній, 2010), S. Grynyuk (Finland) (Гринюк, 2012), M. Levrints (Hungary) (Леврінц, 2011), O. Ozerska (Japan) (Озерска, 2006), O. Zhyzhko (Mexico) (Жижко, 2007) and others. They have suggested the ways of implementation these countries' experience in specialists' professional training in a foreign language at universities in Ukraine. L. Chertok has studied the issue of postgraduate humanitarian education in Switzerland (Черток, 2011). However, the experience of Switzerland in the field of foreign language training has not been learned yet, that has caused our scientific interest to this problem.

Content analysis of the curriculum has been used as the main method applied in the present study; it allowed to identify the characteristic features of organization the training process by students' acquiring their specialty, its structure, content, assessment forms to students' educational achievement.

\section{RESULTS}

The problem of improving the system of professionall and pedagogical training is relevant considering the increasing demands of the state and the labour market to professionals who are subjects of forming the intellectual and spiritual potential of Europe and the world. The effectiveness of competitive specialist's training depends on professional and pedagogical skills of teachers and foreign language teachers. This problem has been actualized by S. Grynyuk: "In modern conditions the ability to use the several languages is acquiring new content ... therefore in the world leading countries the ideas about learning and teaching foreign languages are being transformed in order to provide young people with necessary skills to use foreign languages in international business environment, the labour market...". Language life learning is a condition for overcoming barriers among nations. In this context, formed language competence of personality contributes to successful employment and career development (Гринюк, 2012).

L. Chertok has indicated that in modern conditions it is possible to prepare a specialist in English philology on the basis of competence approach and the principle of intercultural education that is aimed at creation of the intercultural competence.

According to L. Chertok's studies, creation of intercultural competence due to synergetic interaction of different formed competencies is possible within the aspects of intercultural communication pedagogics. The author justifies that in liberal education the dialogue of cultures (intercultural dialogue) is a system formative principle and a method of intercultural approach implementation in education (Черток, 2011).

According to the author Swiss education can be considered intercultural as it admits linguistic and socio-cultural diversity at the level of organization of curricula and teaching methods (Onorati, Bednarz, 2010). Analyzing changes in teacher training in Switzerland 
since 2000, related to the national developed regulations on "Training of teachers on the ground of intercultural approach" with justified aspects and introduction conditions of "Pedagogy of intercultural dialogue" into the Swiss education system, L. Chertok recommends Ukraine to implement the intercultural approach in the program of teacher's training course via "Pedagogy of intercultural dialogue", obligatory inclusion of this course's thematic into programs of other disciplines such as "Teaching Methodology of Foreign Languages" (Черток, 2011).

Taking into account above mentioned statements, we consider appropriate to analyze the implementation of intercultural approach principle into philologists' training in foreign (English) language at Swiss universities.

We have found out that universities of Basel, Fribourg, Geneva and Bern train the Swiss specialists in English language and literature (Study Programmes in English, 2014; Department of English Languages and Literatures, 2014). Bachelors acquire specialty in "English Language and Literature". Name of specialty points at philologist's training (integrated specialist, specialist in linguistics and literature). Education in Bachelor lasts 3 years. The possibility of obtaining the Bachelor's degree is determined by 180 credits ECTS, awarded to a student during the term of successful study at Swiss university.

Content analysis of subjects for Bachelors training in the above mentioned universities allows identifying the main contents features of this training. The curriculum is a list of subjects related to linguistic training: "Introduction to Linguistics", "Introduction to phonetics". Their purpose is to familiarize students with the basics of linguistics as a science of language and basics of linguistic specialty; basic principles of phonetics - the science of sound languages composition, general patterns of sounds production in world languages. Special attention is also given to characteristics of language as a social phenomenon, revealing the influence of social factor on its development and foundation of its role in society; determination of the language value in the structure of the authorities activities, their choice of language policy strategies depending on the characteristics of government in the country and its ethnic composition ("Language and Society", "Language and power", "Language Policy" courses).

It should be noted that at Ukrainian universities, that train specialists in foreign language, courses with such content are absent. Their presence in the curricula of the philologist training in Switzerland, in our opinion, is due to the unique features of the language environment and language policy in the state, what we can prove by the content of the course "Language practice and ideology", which allows to clear up the reasons of focusing on the English learning in Switzerland.

In the process of specialty acquisition attention is focused on the learning of English both in historical perspective ("Earlier English", "English historical phonology", "Hands-on Old English") and in the investigation of its current state ("Modern English Grammar"), which allows to learn the language as a dynamic phenomenon, find out the factors that influenced its development, determine the causes of different linguistic transformations.

Peculiarities of the Bachelor's degree course in English at universities of Switzerland is teaching English in the context of the global world picture ("New languages and new dialects"), and in its narrow functional sense: style and dialectic ("Sociophonetics: acoustic analysis of different speech styles", "Irish English").

The above mentioned subjects have cognitive values as they are integral components of the cognitive content of Bachelor's training. The number of disciplines in practical English acquisition is insignificant. However, one of them is clearly focused on the active learning of English - "Language Policy, Practice and Ideology: A Focus on English in 
Switzerland". It is, in our opinion, similar to a typical domestic philologist training in language, which is a philological discipline of specialty in native universities.

The communicative aspect of English study by Bachelors appears primarily in the acquirement of subjects such as "Exploring Sociolinguistics", "Sociophonetics".

Summarizing content peculiarities of bachelors' linguistic component in Swiss universities, we claim that the active usage of the multicultural approach (English is studied in the context of its understanding as a tool of interaction in conditions of educational and cultural integration of the world nations and a means of constructive polylogue in the state) and brings value to cultural attitudes and linguistic otherness. Attention is paid to understanding and the usage of language as a means of communication. However, the competence approach is the most important in language learning. We believe that during the learning process linguistic and sociocultural competences are being formed.

Training of Bachelors in English Language and Literature in the literary aspect at Swiss universities is well-grounded. However, unlike the domestic professional training of this kind covering well structured acquirement of world literature, Swiss students study the original subjects, the content of which is only associated with the individual, but especially important stages for the development of world literary process ("Displacement, disjunctures and differences in postcolonial literatures and cultures", "How to be a postcolonial critic", "Questions of travel in postcolonial literature", "The fantastic in postcolonial literature"); subjects related to the critical analysis of individual literary genres ("North American story", "Research in the North American imagination limits stories", "The story in American literary history", "Gothic stories", "Fantasy Comics") contribute to increasing the level of students' motivation for the acquisition of literary competence.

The acquisition of literary specialty means the development of the students' specific skills. In particular, the skills to write ("Creative writing"), skillfully perform actions with the text ("Performing text"), influence the audience and keep it interested with help of public speaking performance using piece of art ("Speechifying"), skills of staging dramatics ("Hamlet"), critical analysis of literary works ("History of criticism", "How to be a postcolonial critic").

Research skills that are gained by the students during the study course "From Skin to Book: Medieval Manuscripts". They are improved during the two-day trip to the Stiftsbibliothek St. Gallen. The main forms of BA learning in English Language and Literature at the universities of Switzerland are lectures - traditional and non-traditional (lecture-discussions, lectures with elements of dialogue, polylogue), seminars. The usage of workshops and training sessions, practical training is extensive. BA Colloquiums summarize the content of the studied topics, content modules, being a form of inline control of students' educational achievements.

For the teaching of Bachelors at Swiss universities is carried out under the conditions of credit-modular organization of educational process, final assessment in each discipline during a pass-fail exam or examination is accompanied by calculations of ECTS credits to students for the timely performance of various types of their work such as attending lectures, seminars and their active participation. The final stage of studies for a Bachelor's degree is the development and presentation of a Bachelor's thesis in linguistics or literature (thesis should be written in English). Students need to have a Bachelor's degree for admission to a Master's degree programme. The registration for further study is carried out for this purpose. This procedure is possible under the condition of successful mastering of all the courses and public defense of Bachelor's thesis in length 15,000 words. 


\section{CONCLUSIONS}

Thus, after a content-analysis of peculiarities of professional Bachelors' training in English language and literature at Swiss universities, we have concluded that the students of this educational level are qualified as philologists by acquisition the content of linguistic disciplines and disciplines of literary cycle and content of a particular literature period. Special attention has been paid to the problems of language policy, identification of the reasons of learning English in a multicultural environment such as Switzerland.

The leading methodological approach of Bachelors' formation in English language and literature at the universities of this country is a communicative one that is based on the principle of cross-cultural interaction. Communicative approach and intercultural interaction are basic for learning the context of such educational courses as "Language Policy, Practice and Ideology: A Focus on English in Switzerland", "New languages and new dialects", "Sociophonetics: acoustic analysis of different speech styles", "Irish English", "Language and Society", "Language and power", "Language Policy".

So, the experience of Swiss universities can be adopted by native universities to create communicative personality of professionally competent future philologist with formed socio-cultural and rhetorical competences. Also the Swiss experience of active using multicultural approach to the formation of a Bachelor in philology is rather significant. English is taught in the context of linguistic picture of the world. Attention has also been paid to the comparative analysis of phonetic, pronouncing, grammatical features from other worlds' languages and at the different stages of development and formation that can be implemented in the domestic practice of training in foreign languages.

\section{REFERENCES}

1. Department of English Languages and Literatures (Bern University). (2014). Retrieved 25.11.2014 from : http://www.ens.unibe.ch/content/index_eng.html.

2. Onorati, M., Bednarz, F. (2010). Learning to become an intercultural practitioner: The case of lifelong learning intensive programme Interdisciplinary Course of Intercultural Competences. US-China Education Review, Volume 7, No.6 (Serial No.67), p. 54-62.

3. Study Programmes in English. (2014). Retrieved 25.11.2014 from : http://www.crus.ch/information-programme/studieren-in-deschweiz/studienangebote/studyprogrammes-in-english.html\#c10230

4. Базова, В. I. (2012). Підготовка викладачів іноземних мов в університетах Німеччини [Training foreign language teachers at universities in Germany]. Thesis for a Candidate's Degree in Pedagogical Sciences. Київ, p. 3-222 (in Ukrainian).

5. Базуріна, В. М. (2006). Професійна підготовка майбутніх учителів іноземних мов у Великій Британії [The Professional Future Foreign Languages Teachers' Training in Great Britain]. Thesis for a Candidate's Degree in Pedagogical Sciences. Житомир, p. 3-238 (in Ukrainian).

6. Гринюк, С. П. (2012). Професійна підготовка майбутніх вчителів іноземних мов в університетах Фінляндіï [Professional training of future teachers of foreign languages at universities in Finland]. Thesis for a Candidate's Degree in Pedagogical Sciences. Київ, р. 3-227 (in Ukrainian).

7. Жижко, О. А. (2007). Професійна підготовка вчителів іноземних мов у вищих навчальних закладах Мексики [Professional training of foreign languages' teachers 
in establishments of higher education of Mexico]. Thesis for a Candidate's Degree in Pedagogical Sciences. Київ, р. 3-244 (in Ukrainian).

8. Леврінц, М. І. (2011). Формування мотивації до професійної педагогічної діяльності майбутніх фахівців іноземних мов в Угорщині [Professional pedagogical motivation development of the prospective foreign language specialists in Hungary]. Abstract of thesis for a Candidate's Degree in Pedagogical Sciences. Тернопіль, p. 3-22 (in Ukrainian).

9. Озерська, О. Ю. (2006). Професійна підготовка вчителів у вищих навчальних закладах Японії [Professional teacher training in higher educational institutions of Japan]. Abstract of thesis for a Candidate's Degree in Pedagogical Sciences. Харків, p. 3-22 (in Ukrainian).

10. Черній, Л. В. (2010). Запозичення позитивного досвіду підготовки вчителів іноземної мови у США та його адаптація до вітчизняних вимог [The adoption of positive ideas of foreing language teacher education in the USA and its adaptation to the ukrainian's demands]. Гуманізація навчально-виховного проиесу [Humanization of the educational process]. Issue L, part I, p. 163-171 (in Ukrainian).

11. Черток, Л. П. (2011). Діалог культур у післядипломній гуманітарній освіті Швейцарії [The dialogue of cultures in postgraduate humanitarian education in Switzerland]. Abstract of thesis for a Candidate's Degree in Pedagogical Sciences. Ялта, p. 3-22 (in Ukrainian). 